\title{
How UK Climate Change Policy Has Been Made
}

\section{Sustainable}

\section{David Campbell}

Lancaster University Law School, UK

\section{Introduction: The failure of international climate change policy}

'Alarmed' by the inability of more than a quarter century of international climate change negotiations to make progress towards a legally binding commitment to global reductions in anthropogenic greenhouse gas (GHG) emissions, the UN Secretary General convened a Climate Change Summit in New York on 23 September 2014 (Ban Ki-moon, 2014). As will be described in this article, the current stated aim of negotiations under the UN Framework Convention on Climate Change (UN, 1992: art 2) is to reach a global reductions agreement at the Climate Change Conference to be held in Paris at the end of 2015. The New York Summit was extraordinary in the sense that it was held entirely outside of the UN process in an attempt to give a stimulus to negotiations perceived to have stalled (Brown, 2014; Rowling, 2014). But it was perfectly normal in that, despite some very misleading public pronouncements about its results, it yielded nothing of any substance whatsoever. ${ }^{1}$

It was, however, impossible that it could have had a productive outcome. Although one hundred and sixty two countries were represented, one hundred and twenty two by Heads of State or Heads of Government, with Prime Minister Cameron attending in person, crucially President Xi Jinping of China and Prime Minister Modi 
of India did not attend, despite the strenuous efforts of the Secretary General and other senior figures of UN climate change policy to persuade them to do so (Darby, 2014; Press Trust of India, 2014). President Xi and Mr Modi are the leaders of the two countries which, for reasons which will emerge, will themselves determine whether global emissions reductions can ever take place. Yet again affirming the negotiating position they have adamantinely maintained for more than a quarter century (Gupta and Chaudhary, 2014), ${ }^{2}$ and which, as will be discussed, they strenuously affirmed at the Copenhagen Climate Change Conference in 2009, China and India completely undermined the New York Summit before it began (Westcott, 2014). ${ }^{3}$

Prime Minister Cameron’s attendance at the Summit poses a most serious question about the way UK climate change policy has been and continues to be formulated. His attendance evidences the UK’s belief, in defiance of China's and India's negotiating position, that a global emissions reductions agreement can be reached at the end of 2015. The Secretary of State for Energy and Climate Change went far further than one recognises that his office demands by claiming that the Summit was a 'successful start' to this process of agreement (Davey, 2014).

It is crucial to note that the UK's position is by no means merely a question of a foreign policy stance. Behind that stance lies the simply enormous investment that the UK has made under the Climate Change Act 2008 (CCA) to a domestic policy of 'decarbonisation' in pursuit of global emissions reductions. For, other than Money Bills, there is no body of legislation which will have a greater effect on the prospects for the UK economy than the measures taken in response to what the UNFCCC calls ‘dangerous anthropological interference’ (DAI) in the global climate caused by GHG emissions. The centrepiece of this legislation is the CCA but the Energy Act 2013 is a 
measure of major significance in itself. As with all aspects of debate in this area, the costs which the Energy Act in particular, and the policy of 'decarbonisation' under the CCA in general, have imposed and will impose on UK business, and so, of course, ultimately on UK consumers and taxpayers, is a matter of intense dispute. ${ }^{4}$ That these costs are so immense as to be of macroeconomic significance is, however, beyond dispute, and to say this is, in a very important sense, enough for the purposes of evaluating UK climate change policy. Complicated and controversial estimates of the costs and benefits of that policy are fundamentally redundant because, without a complete change in the international position, it is impossible that UK climate change policy can make any contribution at all to the avoidance of DAI.

31 December 2012 marked the end of the 'First Commitment Period' under the Kyoto Protocol (UN, 1997: art 3(1)). Coming 15 years after the Protocol (and 20 years after the Framework Convention) opened for signature, this was a time to take stock of what climate change action had achieved. Unfortunately, less than nothing had been achieved. GHG emissions were at least $150 \%$ of their level in 1990, the year selected as a baseline for assessing GHG reductions under the Protocol. Not achieving any reductions, indeed not preventing emissions’ very substantial growth, obviously represents the complete failure of international climate change policy so far.

The principal reason for this failure is the growth in emissions by the major industrialising countries, on which, in the interests of brevity, I shall focus on China, though India is in substantial part a duplicate case. China's immense economic growth since 1979, generally at $10 \%$ per annum, has led to it becoming the world's largest emitter, now responsible for more than $30 \%$ of global emissions. What is more, China still has much to do. China has a population of over 1.3 billion, ie it has a billion more 
people than the USA. The benefits of China's growth have been concentrated on the more than 250 million now living in or around its major coastal cities. Its hinterland population is still very poor. There are approaching a billion people in China living on less than US\$5/day and over 500 million living on less than US\$2.50. This is reflected in China's per capita emissions still being a third of those of the USA. If China's policy of extending the benefits of its growth to its poverty stricken hinterland is successful, the growth of its emissions will itself continue to make global reductions impossible.

Unless it is reversed, China's position makes the UK’s climate change policy irrational. The UK is responsible for $2 \%$ of global emissions. Nothing it can itself do can secure global reductions. Nothing the EU or all the developed world can do can secure global reductions unless the trajectory of Chinese emissions is radically changed. Without such change, the immense costs imposed by the CCA can yield no benefit at all.

Nevertheless, the principal agency charged with providing the UK government with advice on climate change policy, the Committee on Climate Change (CCC), has, in Part $1^{5}$ of its widely publicised (eg Chestney, 2014; Gosden, 2014; Harribin, 2014) Fourth Carbon Budget Review (CCC, 2013b: ch 2) emphatically endorsed continuation with the decarbonisation policy after having considered the 'international circumstances' of its application. This article examines the nature of this advice as a key element of the process of policy formulation that has made it possible for the UK government to sustain its climate change policy.

This article is not, in the first instance, an article about climate change policy, but is about the constitutional and administrative law of that policy. What I have just 
written about China and India summarises an argument, which my colleagues and I first placed in the public domain in 2007, that unless China (and India) completely change their positions there will be no global emissions reductions (Campbell, Klaes and Bignell, 2010a; Campbell, 2013a). Though I refer the reader to these papers, I will not go further into their argument here because, to all those whose views are based on a respect for the facts, whether they are in favour of the UK's policy or not, the significance of the position of China (and India) is no longer a controversial issue. In the reported words of Professor Corinne Le Quéré, lead author of the Global Carbon Budget and Director of the Tyndall Centre for Climate Change Research, 'carbon savings by other countries will make little difference unless they are matched by the world's most populous nation' (Webster, 2013). ${ }^{6}$ It therefore cannot be a matter of rational dispute that the UK's policy should be formulated on the basis of appropriate weight having been given to the grave problem China (and India) pose. But this is exactly what has happened. The significance of this problem has been systematically underestimated by the CCC, and its advice has been, as a result, valueless. This article is a discussion of the constitutional and administrative law framework for policy formulation which has made this possible.

\section{Not facing unpleasant facts}

Established under pt 2 of the CCA, where it is described as 'a body corporate' (CCA, s 32(1), Sched 1), the CCC is, in the terminology of contemporary administrative law, an independent agency, though, even in these days of extensive regulatory innovation (Black, 2005), it has uncommon features. ${ }^{7}$ It has no executive powers but is charged with, inter alia, giving independent, expert advice on setting, and then reviewing, the 
'carbon budget' (CCA, s 4), the legally binding emissions limit intended to give effect to the CCA's policy of decarbonisation such that by 2050 UK emissions will be $80 \%$ less than they were in 1990 (CCA, s 1). Though a proposal advanced in the debate on the Climate Change Bill that the CCC’s advice should be more or less automatically followed was not adopted (Environment Food and Rural Affairs Committee, 2007: para 86), pt 2 of the CCA makes it plain that the Secretary of State for Energy and Climate Change must pay great heed to that advice, and it has proven to be extremely influential on energy policy (HM Government, 2012). Four carbon budgets have so far been introduced on the basis of CCC advice, the most recent, for the years 2023-7, coming into force on 30 June 2011 (The Carbon Budget Order 2011). This budget is conceived as being in line with the 2050 target.

Under CCA s 10(2)(h), the CCC is specifically charged with taking ‘circumstances at European or international level' into consideration when giving its advice, and ch 2 of pt 1 of the Review accordingly considers 'international circumstances'. Though noting that 'progress towards a global deal has been slow' and that further progress will be 'very challenging', the CCC concludes 'that there is no rationale [sic] to change the fourth carbon budget' because 'global emissions pathways consistent with the [UK] climate objective remained feasible and were a suitable basis for UK policy' (CCC, 2013b: 41, 58, 38, 40). This is prima facie a very surprising conclusion in light of the position of the newly industrialising countries. It is based on an analysis of China's position specifically, but this must be set in the context of international climate change measures, particularly the UN negotiating process, more generally, and to these we now turn. 


\section{The UN process}

The CCC's evaluation of international climate change law is markedly optimistic:

The key point for assessing the fourth carbon budget is that the UN process has moved forward, and is now focused on getting agreement on emissions cuts to 2030 consistent with limiting warming to $2^{\circ} \mathrm{C}$ (CCC, 2013b: 41).

The foundation of this optimism is a claim that 'the Copenhagen Conference of the Parties ... had agreed the Copenhagen Accord which set out that the climate objective should be to limit global temperature increase to $2^{\circ} \mathrm{C}$ ', and that one of the 'key results' of the subsequent conferences in Cancun (2010), Durban (2011) and Doha (2012) had been 'to formally incorporate the $2^{\circ} \mathrm{C}$ objective into the UN process' (CCC, 2013b: 38). Whilst the meaning of 'had agreed', 'set out' and 'formally incorporate' is ambiguous, if that meaning is that the UN process has adopted the $2^{\circ} \mathrm{C}$ target in any concrete, not to speak of legally binding, way, then this is quite wrong. Four points must be borne in mind.

First, the Copenhagen Conference was unable to agree anything at all through proper UN negotiating channels, and was saved from utter embarrassment only by the action of a self-selecting group of five countries, Brazil, China, India, South Africa and the USA, which drafted the Copenhagen Accord, an informal document of no legal status of which the Conference of the Parties merely 'took note' (Conference of the Parties, 2010: Decision 2/CP/15). The use of the phrase 'had agreed' to describe, without proper qualification, the result of a Conference which threw climate change policy across the world into turmoil because of its failure to agree anything in line with UN processes is highly misleading.

Secondly, the $2^{\circ} \mathrm{C}$ target was unilaterally formulated and promulgated by the 
EU Commission (2010) as it became conscious of the stalling of the UN negotiating process. As the CCC (2013b: ch 3) itself commendably acknowledges, that target has never been adopted even within the EU, if by adopted one means made legally binding and a programme of emissions reductions in line with it put in place. The EU's own basic policy, now called the 2020 Climate and Energy Package, is of a 20\% reduction in emissions and a 20\% growth in renewables by 2020 (European Parliament and Council of the European Union, 2009). This itself is completely arbitrary in that it is not and cannot be related to any target for global emissions reduction, much less the $2^{\circ} \mathrm{C}$ target.

Thirdly, whilst it is true that the $2^{\circ} \mathrm{C}$ target was inserted into the Copenhagen Accord and the reports of the subsequent Conferences, this is always merely in the form of an objective rather than a commitment to concrete action of any sort.

Paragraph 1 of the Accord says that:

To achieve the ultimate objective of the [Framework] Convention to stabilize greenhouse gas concentration in the atmosphere at a level that would prevent dangerous anthropological interference with the climate system, we shall, recognizing the scientific view that the increase in global temperature should be below $2^{\circ} \mathrm{C}$, on the basis of equity and in the context of sustainable development, enhance our long-term co-operative action to combat climate change (Conference of the Parties, 2010: Decision 2/CP/15, para 1).

If this is an agreement to do anything, it is an agreement, not of the $2{ }^{\circ} \mathrm{C}$ target, but only to ‘enhance ... long-term co-operative action’. Many Parties did indeed agree to notify the Climate Change Secretariat of any such action they might unilaterally and voluntarily undertake (Conference of the Parties, 2010: Decision 2/CP/15, paras 4-5). Despite the CCC following common climate change policy usage by calling them 'pledges', these notifications gave no undertaking to make absolute emissions 
reductions and most vehemently rejected the possibility that they might do so. China's entirely representative notification will be discussed below.

In all the subsequent climate change conferences, nothing of more compelling legal form or of more concrete substance has been agreed. What has been said is that something concrete will be agreed by 2015. The CCC describes the process thus:

In 2011 there was agreement under the 'Durban Platform' to adopt a new global deal in 2015, applicable to all countries and coming into effect in 2020 (i.e. to cover the period after the 2020 pledges made in the 2009 Copenhagen Accord). This process is ongoing, with interim negotiations at Warsaw (2013) and Lima (2014). In addition, in 2014 the UN Secretary-General will host a leaders conference aimed at developing ambition ahead of negotiations in Paris in 2015 ... The Durban Platform provides the opportunity to address this challenge, with the aim that agreement is reached in Paris by the end of 2015 (CCC, 2013b: 40).

Leaving aside points of detail, what surely is completely unacceptable with this if it is considered as advice to the Secretary of State is that it does not put this optimistic prediction of what will be done in the utterly disappointing context of what actually has been done so far, which is nothing. (It was this that led the Secretary General to convene the extraordinary New York Summit, and it was entirely in line with this that that Summit achieved nothing of substance). The CCC was obliged to qualify its claim about the 'ongoing' 'opportunity' by giving advice that there is every reason to doubt that the opportunity will be taken. But the CCC does not even mention that the very same process charged in 2011 with reaching a binding reductions commitment by 2015 had failed to reach any such commitment in over a quarter century of previous negotiations.

Fourthly, the fundamental reason the UN process has failed to agree an emissions reduction target is that the most important provision it actually has agreed is an insuperable obstacle to any such target. We have seen that para 1 of the 
Copenhagen Accord merely posed the $2{ }^{\circ} \mathrm{C}$ as an abstract objective. Para 2 goes on to

say:

We agree that deep cuts in global emissions are required according to science, and as documented by the IPCC Fourth Assessment Report with a view to reduce global emissions so as to hold the increase in global temperature below 2 degrees Celsius, and take action to meet this objective consistent with science and on the basis of equity. We should cooperate in achieving the peaking of global and national emissions as soon as possible, recognizing that the time frame for peaking will be longer in developing countries and bearing in mind that social and economic development and poverty eradication are the first and overriding priorities of developing countries and that a low-emission development strategy is indispensable to sustainable development (Conference of the Parties, 2010: Decision 2/CP/15, para 2).

The distinguishing of the position of the developing countries and the acknowledgement that 'social and economic development and poverty eradication are the first and overriding priorities' of those countries is a reference, within the Accord, to art 4(7) of the Framework Convention, which provides that:

The extent to which developing country Parties will effectively implement their commitments under the Convention ... will take fully into account that economic and social development and poverty eradication are the first and overriding priorities of the developing country Parties (UN, 1992: art $4(7))$.

Affirmed at Kyoto and at all of the climate change conferences subsequent to Copenhagen which the CCC mentions, this actual treaty provision is an effective permission to the developing countries to emit as much as they find necessary for their economic growth. Climate change policy can work only if it caps emissions. Whilst there never have been any caps on any countries’ emissions which are related to a global target for emissions reduction, there have been some actual caps placed on the emissions of the developed countries. But under the 'common but differentiated' responsibilities strategy at the heart of international climate change negotiations, 
which states that the developed countries 'should take the lead in combating climate change' (UN, 1992: art 3(1)), no caps have ever been placed on developing countries, and art 4(7) effectively stipulates that there cannot be. As the Framework Convention, and later the Kyoto Protocol, placed the major industrialising countries, including China and India, within the category of developing countries, this has meant that no cap can be placed on countries the emissions of which alone make global emissions reductions impossible. As I have put it elsewhere, the 'common responsibility [of the major industrialising countries] is so differentiated that it does not exist' (Campbell, 2013a: 128). It is utterly pointless, then, to place caps on developed countries. No conceivable reduction in their emissions can secure global reductions.

It is highly regrettable that the CCC gave advice which does not convey the existence of this very serious problem, which cannot possibly be solved under the Framework Convention, though that problem informs the main provisions of the Copenhagen Accord on which the CCC principally rested that advice.

The Carbon Budget Review was released on 7 November 2013 (CCC, 2013a). Before the end of the month, the successor to the Doha Climate Change Conference, held in Warsaw between 11 and 22 November, saw the further abandonment of the goal of setting any global target for absolute emissions reductions. The Conference was, of course, proclaimed a success (UN Climate Change Secretariat, nd), and the goal of determining a target in 2015 was maintained, the drafting being left in the hands of an ad hoc working group (Conference of the Parties, 2014: Decision 1/CP/19). But the concrete, if this is the right word, step taken in pursuit of this goal was:

To invite all Parties to initiate or intensify domestic preparations for their 
intended nationally determined contributions, without prejudice to the legal nature of the contributions, in the context of adopting a protocol, another legal instrument or an agreed outcome with legal force under the Convention (Conference of the Parties, 2014: Decision 1/CP/19, para 2(b)).

The novel feature is the use of 'contribution' to describe what the CCC calls a pledge, for, not satisfied with yet another categorical 'without prejudice' statement, China (and India) utterly refused to agree the use of the word 'commitments' in drafting this decision, and the fractious negotiations went well beyond the eleventh hour until use of the sufficiently vague term of 'contributions’ was accepted (Ritter, 2013).

This example of the apparently now settled but very tedious and exasperating ${ }^{8}$ practice of prolonging otherwise failed negotiations by agreeing verbiage (Rekley and Twidale, 2013) was entirely predictable, and indeed widely predicted (McGrath, 2013), at the time of the release of the Review; long before in fact. So poor was the CCC's assessment of the international circumstances affecting the UK's climate change policy that it could advise the Secretary of State that things broadly were going well at the very time that the UN process was even more clearly grinding to a halt, as was further confirmed at the New York Summit.

\section{China}

The essence of the CCC's advice about China is that:

In the Copenhagen Accord China pledged to reduce its carbon intensity by 40-45\% by 2020 compared to 2005 levels. In 2011 China adopted its 12th five-year plan, covering the period 2011-15. This set out the policies planned to put China on track to meet its 2020 carbon intensity target ... Evidence suggests that measures already in place, together with those set out in the 12th five-year plan, mean the high ambition of China's Copenhagen Pledge for 2020 is achievable ... recent policy announcements, if agreed and delivered, could put Chinese emissions on a trajectory consistent with the global emissions pathways required to meet 
our climate objective (CCC, 2013b: 42-43).

Accepting this for the purposes of argument, two points should be made about it.

First, by 'Copenhagen Pledge' the CCC means the notification which China made under the Accord. It has already been noted that these notifications, and the Accord itself, have no legal status as a function of the way they were arrived at within the UN process. But, not content with this, the Chinese notification itself is significantly different to the way it is described by the CCC. Whereas the CCC claims that 'In the Copenhagen Accord China pledged to reduce its carbon intensity by 4045\% by 2020 compared to 2005 levels', the wording of the notification is that 'China will endeavour to lower its carbon dioxide emissions per unit of GDP by 40-45\% by 2020 compared to the 2005 level', and immediately asks those reading this to:

note that the above-mentioned autonomous domestic mitigation [action] would be voluntary in nature and will be implemented in accordance with the principles and provisions of the UNFCCC, in particular Article 4, paragraph 7 (Su Wei, 2010). ${ }^{9}$

Nothing of the insistently voluntary quality of this pledge that would be conveyed by mentioning that it is adamantinely informal and made explicitly subject to the article of Framework Convention that means that China can never be required to cap its emissions emerges from the CCC’s advice.

But secondly, and even more significantly, it must be noted that China's endeavour is to lower carbon intensity. Reduction in carbon intensity and reduction in absolute emissions must be strongly distinguished. Carbon intensity is a measure of the amount of GHG which must be emitted to obtain a certain increase in GDP. Such a reduction carries no implication that it will involve an absolute reduction of emissions, though, really scarcely credibly, the CCC makes no mention of this, and so 
its advice would lead its recipient to believe that what is being proposed will lead to an absolute reduction which in some way is linked to achievement of the $2^{\circ} \mathrm{C}$ target. This advice is completely misleading.

Broadly speaking, absolute emissions and economic growth are strongly correlated, but, with increasing sophistication of technology, the rate at which growth requires emissions, that is to say, carbon intensity, falls. China's economic growth will, as the CCC claims, involve a reduction of carbon intensity as new plant is installed and old plant is retired. But reduction in carbon intensity may be perfectly consistent with unbounded absolute growth in emissions, depending on how much economic growth there is, and such are the economic growth targets of the major industrialising economies that their reductions in carbon intensity will be made, not despite but because of, a growth in absolute emissions. China will not retire existing generating capacity and replace it only with an equivalent or smaller capacity generated by lower intensity plant. It will retire older capacity in the course of an immense expansion of overall capacity. In such circumstances, as new plant is installed and old plant is retired, carbon intensity falls, but the fall is obtained through absolute growth of emissions, and the faster the fall in intensity, the greater the rise in absolute emissions. The CCC itself claims that, without investment which reduces carbon intensity, Chinese emissions would have been 19\% higher in 2011 (CCC, 2013b: 42). But, again accepting this for the purposes of argument, this is hardly the positive achievement the CCC depicts, for it does not say anything about the level of absolute emissions, and the CCC itself states (2013b: 42) that these have grown by 290\% since 199! China's extremely ambitious and apparently positive intensity targets actually represent a statement that the increase in its emissions will be vast. 
That the CCC does not even consider this argument, or give advice which elucidates the distinction between absolute emissions and carbon intensity necessary to understand it, are profound failures.

\section{Summary}

I believe that the twenty one pages of the CCC's advice on international circumstances contain more than a score of other claims that are either in complete error or are so tendentious as to be very seriously misleading. The worst of these is the repeated claim that various important emitters, such as Japan, have reductions 'commitments comparable to the UK's' (CCC, 2103b: 10) when, not only were these commitments always very substantially legally different, but, even if Japan can be said to remain within the UN negotiations - and Japan was at least represented at the New York Summit by its Head of Government - it is perceived by those committed to those negotiations to have undermined them (eg Lean, 2014) by, inter alia, actually having abandoned the Kyoto process, in considerable part in response to the position of the major industrialising countries (Ishahara, 2013; Ministry of Foreign Affairs of Japan, 2010). ${ }^{10}$

However, further discussion is unnecessary. What we have seen of its advice about the UN process in general and about China in particular is sufficient to convey the quality of the CCC's advice. At the very least, that advice had to put its optimistic picture of progress towards a 2015 binding commitment to global emissions reductions in the context of a quarter century of previous failure to achieve any such commitment; had to put the Copenhagen Accord in its proper legal context, especially in the light of the Accord's own clear statement that it is subordinate to art 4(7) of the 
Framework Convention, and had to indicate that commitments to reductions in intensity carry no implication of absolute emissions reductions and, indeed, in the circumstances of China, will mean a vast growth in absolute emissions. In my own opinion, the position really could not be more bleak. However this is, any reasonable advice would have had to convey the history of disappointment and the extremely unpromising basis for any future binding commitment.

In light of this, the attitude displayed by the CCC is really rather remarkable. Despite being widely regarded as one of the greatest of Twentieth Century writers of English prose, George Orwell's reputation rests, not so much on his 'facility with words' (Orwell, 2001/1946: 316), as on his ability to identify telling things to write about and to write about them with telling objectivity. He had, as he claimed for himself, a 'power of facing unpleasant facts' (Orwell, 2001/1946: 316). The Fourth Carbon Budget Review evidences a complete absence of this power. The advice it provides to the Secretary of State ritually mentions and then completely fails to discuss the extremely concerning counter-evidence to the optimistic message it conveys. Even when that message is not itself based on outright error, it is never balanced. Such advice is not, in a very strong sense, advice at all. And, setting aside the likely complete lack of merit of the climate policy based on such advice, that the CCC can so fail in its statutory duty gives rise to issues of great regulatory and constitutional concern.

\section{Conclusion: government failure under the new public management}

Perhaps the greatest achievement of the late Ronald Coase was his contribution to the demonstration that regulatory policy formulation in the tradition of Pigouvian welfare 
economics rests on a number of logical fallacies, one of which was that identification of a 'market failure' itself justified intervention. This is not so. Any such justification must also show that intervention will produce a superior level of welfare. This second stage of the argument for intervention often is ignored because it is assumed that the institutions necessary to carry out the intervention are or can be made available and will work as envisaged. Coase called policy made on the basis of this assumption 'blackboard economics’: the policy will work on the blackboard; unfortunately it may well be that it cannot be put into practice (Williams Jr and Coase, 1964: 195). International climate change policy is one of the most blatant examples of this sort of thinking in the history of economic policy. Not only has seriously inadequate attention been paid to the possibility of creating the institutions needed to get the policy to work, the very drafting of the Framework Convention itself made it impossible to create those institutions! No amount of argument about the size of the 'externality' of global warming produced by GHG emissions can alter this. It does not even speak to it.

What was needed, Coase told us, was a concept of 'government failure' to complement our concept of market failure (Williams Jr and Coase, 1964: 195), and in the period after the publication of 'The Problem of Social Cost' (Coase, 1960) Coase had the satisfaction of seeing this concept develop as part of the neo-liberal revolution in our attitude towards intervention and, indeed, towards traditional forms of government in general. The CCC is itself a product of the 're-conceiving' (Sunstein, 1990) of the 'regulatory state' (Majone, 1994) consequent upon this revolution (Stallworthy, 2009: 417-18). ${ }^{11}$ It exemplifies the ‘de-centering’ (Black, 2001) of policy formulation away from central government and its civil service, and its 
legitimacy is to lie in the independence and expertise manifested in the advice generated by the de-centered process (Baldwin, 1995: 45-46), to which great heed therefore must be paid by government. No body is more aware of this than the CCC, the home page of which proclaims in the banner at its head that the CCC's 'independent, evidence-based advice to the UK Government and Parliament' is the basis of 'a balanced response to the risks of dangerous climate change' (CCC, nd). When that advice is tendentious to the point where it can barely be described as advice at all, something surely has gone drastically wrong. It has been authoritatively argued that innovation by the reformed British regulatory state has a tendency to lead to fiasco (Moran, 2003: 171-79). Steeply rising 'green’ components of energy (and therefore all other product) prices and the prospect of grid failure are now obliging the electorate to realise that UK climate change policy has enormous costs. These can only possibly be borne if that policy is outweighed by its benefits. But as there has been no reduction in global emissions, and as there never could have been, nor will there ever be, any such reduction under the Framework Convention, then the benefits of UK decarbonisation are zero, the cost-benefit calculation is hugely negative, and climate change policy joins the set of fiascos. If we give any weight to Coase's belief that 'the demand for nonsense seems to be subject to the universal law of demand: we demand less of it when the price is higher' (Coase 1994/1975: 55), then how such a state of affairs could come about and be maintained long after climate change policy's failure should have been clear is an interesting question for contemporary regulatory theory. That a body established as part of a process which has sought to 'overcome' the 'familiar regulatory difficulties' of the castigated government by command and control (Baldwin, 1996: 65) provides advice of this very poor quality is an important 
part of the explanation of government failure à la mode.

\section{Afterword, May 2015}

By courtesy of the Editor, I am able to add a few words in explanation of the somewhat unusual circumstances of the publication of the foregoing article, which was first drafted in 2013.

In 2007, Matthias Klaes, now a Professor at the University of Dundee, and I were invited to give a paper at a conference commemorating the tenth anniversary of the publication of Luhmann's Die Gesellschaft der Gesellscahft. ${ }^{12}$ Klaes and I were and remain fascinated by systems theory, but our fundamental concerns were and are with the practical evaluation of regulation. It was therefore not only because of the importance of ecology in Luhmann's thought but because we believed it was a topic particularly suited to gauging the value of that thought for our practical concerns that we decided to present a paper on international climate change policy. We approached that policy conscious that it constituted a step change in the scale and scope of environmental intervention - we came to call it the first instance of a 'new global welfare economics’ (Campbell, Klaes and Bignell, 2010a: 164) - and that the quasimarket technique of the intervention was influentially claimed to be an application of the views of Ronald Coase, who Klaes and I believe to be one of the most important post-war contributors to the theory of the evaluation of regulation (I myself believe he is the most important).

The resulting paper, eventually written up with the assistance of Chris Bignell, then my student and research assistant at Cardozo Law School which I was visiting, now in legal practice, did not meet the purposes of the conference. Klaes and I were 
unable to put our thoughts into what the prevailing view at the conference would regard as an authentically Luhmannian vein because we had and have difficulty accepting the meaning Luhmann gave to the concept of reflexivity and to the concept of the autonomy of systems on which reflexivity as he understands it rests (Campbell, 2013b: 174-81). I shall return to this. Instead, researching the paper led to our views on international climate change policy, of which mitigation of global warming by reduction of anthropogenic greenhouse gas emissions remains the most important pillar, becoming profoundly Coasean, but not in the sense meant by the advocates of quasi-market technique.

Though law and economics has to some considerable extent become identified with market mimicking, this is predominantly the result of Posner's influence. To my knowledge, Coase has nowhere advocated a market mimicking approach to environmental issues, a line which was actually opened principally by JH Dales (1968; 2002/1968), ${ }^{13}$ and Coase's only comment (Coase, 2012: x) on international climate change policy of which I am aware is a very brief and sceptical one in the foreword he provided to a book on derivatives written by Richard Sandor, who had earlier come to Coase's attention when he wrote a most interesting paper on plywood futures contracts which Coase published in The Journal of Law and Economics.

The sense in which the mitigation policy is Coasean is that it is blatantly open to Coase’s criticism of ‘blackboard economics’ (Williams Jr and Coase, 1964: 195). What has been done is overwhelmingly based on abstract welfare economics and no remotely adequate inquiry has ever been made into the plausibility of the assumption that the institutions necessary to achieve global emissions reductions can be put in place. The argument for mitigation in the Fourth Assessment Report 
(Intergovernmental Panel on Climate Change, 2007) and in the Stern Review (Stern, 2007) is one of the worst exercises in blackboard economics ever perpetrated. Klaes and I approached our Luhmann paper with the suspicion that the quasi-markets in emissions, of which what is now the EU Emissions Trading System remains by far the largest, would prove immensely difficult to devise and enforce, and the troubled history of the EU System certainly confirms this. But it quickly became apparent to us that such difficulties, which are at least in principle resolvable, ${ }^{14}$ were almost irrelevant.

For the treaty law on which international climate change policy is based not only does not include a global emissions reduction commitment but actually gives undeveloped countries an express permission to give economic growth 'first and overriding’ priority over emissions reductions (United Nations, 1992: art 4(7); 1997, art 10, art 11(1)). Caps therefore cannot be imposed on these countries. As the emissions of China alone, though India is an essentially similar case, have made and will make global emissions reductions impossible, and as China and India are classified as undeveloped countries by the Framework Convention, the impossibility of global emissions reductions was built into the legal foundation of international climate change policy. The Clean Development Mechanism which was intended nevertheless to lead to emissions reductions in the undeveloped countries cannot, by the very nature of its design, lead to any global emissions reductions whatsoever and the way in which it has operated would be a scandal comparable to the Iraq Oil for Food Programme were it sufficiently well known. Set in this international context, UK climate change policy, based on very arguably the world's most demanding emissions reductions commitment, is irrational. It has already cost the citizens of the 
UK tens of billions, and it will cost trillions to the extent it is rolled out, although it cannot possibly achieve any reduction in global emissions.

These research results have proven very difficult to publish. Submitted papers have been rejected by reviewers often described to me by editors as 'climate change experts' in a scornful way I have never previously encountered in now more than 40 years of publication. In line with the reviews of other submissions, the paper to which this is a prefatory note has been described by reviewers for journals which rejected it as, amongst other things, 'a rant' and something suitable for an argument 'in the pub'. It proved impossible to place the Luhmann paper in a UK journal and it appeared in the journal of an Australian law school where I had given a staff seminar based on that paper (Campbell, Klaes and Bignell, 2010a), though a summary version did later appear in a UK economic policy journal (Campbell and Klaes, 2011). An editor who did give space to a later paper (Campbell, 2013a) in an environmental law journal published in the UK was then subjected to such sub rosa criticism for doing so that he felt obliged to offer his resignation, which was thankfully not accepted. I could go on.

Despite these difficulties, this work has attained a certain presence in the public sphere. The Australian law journal in which it was published is the journal of one of that country's leading law schools. The environmental law journal in which it was published is one of the common law world's leading journals on the subject. The economic policy journal in which it was published is influential. The work also has been made available as an LSE Working Paper (Campbell, Klaes and Bignell, 2010b) and through this on SSRN. Though I am afraid I keep no accurate total of these things, I am aware that these publications have been downloaded more than a thousand times. Lectures and seminars based on this work have been presented on 
more than a score of occasions at universities and business fora on four continents between New York and Auckland. The work has once or twice been commented upon in newspapers, and in particular The London Review of Books has allowed me access to its letters pages in a way which, given the likely views of its readership and the commercial constraints under which it operates, I think is highly laudable. In light of all this, it therefore may be thought puzzling that this work has not received public criticism. But, in stark contrast to the reviews, so far as I am aware, it has received no such criticism.

The paper to which this is an afterword was drafted at the end of 2013 following the publication by the Committee on Climate Change of the first part of its Fourth Carbon Budget Review (Committee on Climate Change, 2013b). Given the opportunity, if I may put it this way, to do so by its being rejected by numerous UK journals, I revised it over the course of 2014 in order to take into account various developments, and the version published here is one drafted immediately after the failure of Secretary General Ban Ki-moon’s Climate Change Summit held in New York on 23 September 2014, which the President of China and the Prime Minister of India did not attend. Very reluctantly and I must confess somewhat desperately, I brought my difficulties publishing this paper to the attention of my colleagues on the Editorial Board of Social and Legal Studies and asked them to consider publishing it. The decision was taken to make the paper the basis of a Dialogue and Debate section of the journal. I thought this very fair and wise, and indeed the best thing to do, save that, I am bound to say, I did not think there would be sufficient takers for the Dialogue and Debate, and so, with one (perhaps two) honourable exception(s), it has proved. I am immensely grateful to my colleagues that, in light of this, they have 
decided to publish the paper on its own.

I have decided not to further update the paper (save in trivial ways). I am happy to predict what will happen at Paris Conference to be held at the end of this year on the basis of the material in the paper and the earlier work it summarises. As regards the fundamental issue of achieving a legally binding and meaningfully biting commitment to global emissions reductions, in practical, Coasean terms, nothing will happen. Despite the variously named international climate change negotiations in the wake of Copenhagen being predicated on the Paris Conference yielding such a commitment - the Paris Protocol it is now being called (European Commission, $2015)^{15}$ - it will not do so unless the meaning of binding is relaxed beyond all legitimate usage, as indeed it will be in most official and much media comment after the Conference (indeed, the process has already begun). ${ }^{16}$ Over the more than a quarter century between the creation of the Intergovernmental Panel on Climate Change in 1988 and the Paris Conference, the mitigation policy will have incurred simply astronomical costs and yielded no benefit whatsoever.

But the understanding of the mitigation policy on which this prediction is based is now rather tired. Klaes and I reached it on the basis of merely a few months of research in 2007. Had we done the research in 1997-98, after the Kyoto Protocol, or even in 1992-93, after the Framework Convention, I am sure we would have reached the same conclusion just as quickly. The fundamental legal position was clear enough then, as was China's growth trajectory (though much less so India's.) The live intellectual issue is not the failure of mitigation. The live issue is how the mitigation policy has been sustained over this long period, especially after its failure was made blatant by the farcical result of the Copenhagen Conference. It is this issue, not the 
failure of the mitigation policy, that the paper addresses. This paper merely summarises the argument about the mitigation policy made in previous work and is addressed to the, as it were, sustainability of a policy which could never succeed, has markedly failed, and never can succeed.

And with this I must return to the point on which I began this Afterword. The prediction I have confidently made of the outcome of the Paris Conference in obtaining a commitment to global emissions reductions is based on practical, Coasean terms of evaluation of the mitigation policy. But the issue surely arises whether these are the appropriate terms. For I have far less confidence predicting whether, and no confidence predicting when, the policy will be abandoned. I have only a limited understanding of how it is that it was not abandoned after Copenhagen, if not earlier. Should the result of the Paris Conference be a persistence with this policy similar to that which eventually followed Copenhagen, this will be evidence that the UN Climate Change Secretariat and the new global welfare economics of which it is the centre is a functionally differentiated system capable of maintaining autonomy from its environment, and Klaes' and my inability to express our analysis of the international climate change policy in Luhmannian terms will be further called into question.

\section{References}

Baldwin R (1995) Rules and Government. Oxford: Clarendon Press Baldwin R (1996) Regulation: After “Command and Control”. In: Hawkins K (ed) The Human Face of Law. Oxford: Clarendon Press, pp.65-84 
Ban Ki-Moon (UN Secretary General) (2014) Now Is the Time to Act on Climate Change. The Huffington Post, 2 September. Available at:

http://www.huffingtonpost.com/ban-kimoon/now-is-the-time-to-acton_b_5738574.html (accessed on 5 May 2015)

Black J (2001) Decentring Regulation: Understanding the Role of Regulation and Self-regulation in a "Post-regulatory" World. Current Legal Problems 54(1): 103-46 Black J (2005) What is Regulatory Innovation?’ In: Black J, Lodge M and Thatcher M (eds) Regulatory Innovation. Cheltenham: Edward Elgar, pp.1-15 Boyd R, Stern N and Ward B (2015) What Will Global Annual Emissions of Greenhouse Gases Be in 2030, and Will they Be Consistent with Avoiding Global Warming of More than $2{ }^{\circ} \mathrm{C}$ ? ESRC Centre for Climate Change Economics and Policy and Grantham Research Institute on Climate Change and the Environment Policy Paper. Available at: http://www.lse.ac.uk/GranthamInstitute/wpcontent/uploads/2015/05/Boyd_et_al_policy_paper_May_2015.pdf (accessed 5 May 2015)

Brown P (2014) New York Summit is Last Chance to Get Consensus on Climate Before 2015 Talks. The Guardian, 4 September. Available at: http://www.theguardian.com/environment/2014/sep/04/new-york-summit-is-lastchance-get-consensus-on-climate-before-2015-talks (accessed on 5 May 2015) Campbell D (2013a) After Doha: What Has Climate Change Policy Accomplished? Journal of Environmental Law 25(1): 125-36

Campbell D (2013b) Luhmann Without Tears. Legal Studies 33(1): 162-86 Campbell D and Klaes M (2011) Copenhagen, Cancun and the Limits of Global Welfare Economics. Economic Affairs 31(2): 10-16 
Campbell D, Klaes M and Bignell C (2010a) After Cancun: The Impossibility of Carbon Trading. University of Queensland Law Journal 29(2) 163-90

Campbell D, Klaes M and Bignell C (2010b) After Copenhagen: The Impossibility of Carbon Trading. Department of Law, London School of Economics Working Paper 22-2010. Available at http://www.lse.ac.uk/collections/law/wps/wps1.htm (accessed 5 May 2015)

The Carbon Budget Order 2011, SI 2011/1603

Chestney N (2014) UK Should Not Weaken Fourth Carbon Budget, Advisers Say. Reuters, 7 November. Available at: http://uk.reuters.com/article/2013/11/07/ukbritain-carbon-idUKBRE9A60DY20131107 (accessed on 5 May 2015)

Climate Change Act 2008 c 27

Coase RH (1960) The Problem of Social Cost. 3 Journal of Law and Economics 3144

Coase RH (1994/1975) Economists and Public Policy. In: Coase RH Essays on Economics and Economists. Chicago, IL: University of Chicago Press, pp. 47-63 Coase RH (2012/1968) Foreword: In Sandor R Good Derivatives. Hoboken NJ: John Wiley, pp. ix-xi

Committee on Climate Change (2013a) Committee on Climate Change Assessment of Science and International Circumstances Reinforces Existing Fourth Carbon Budget. CCC Press Release, 7 November. Available at:

http://www.theccc.org.uk/pressreleases/committee-on-climate-change-assessment-ofscience-and-international-circumstances-reinforces-existing-fourth-carbon-budget/ (accessed on 5 May 2015) 
Committee on Climate Change (2013b) Fourth Carbon Budget Review: Part 1:

Assessment of Climate Risk and the International Response. Available at:

http://www.theccc.org.uk/publication/fourth-carbon-budget-review-part-1/ (accessed on 5 May 2015)

Committee on Climate Change (2014c) ‘Owen Paterson’s Speech To the GWPF: The CCC’s Response. Available at: http://www.theccc.org.uk/wp-

content/uploads/2014/10/Owen-Patersons-speech-to-the-GWPF-the-CCCsresponse.pdf (accessed on 5 May 2015)

Committee on Climate Change (nd) Banner. CCC website. Available at:

http://www.theccc.org.uk/ (accessed on 5 May 2015).

Conference of the Parties (2010) Report of the Copenhagen Conference. UN

FCCC/CP/2009/11/Add1. Available at:

http://unfccc.int/resource/docs/2009/cop15/eng/11a01.pdf (accessed on 5 May 2015)

Conference of the Parties (2014) Report of the Warsaw Conference. UN

FCCC/CP/2013/10/Add.1. Available at:

http://unfccc.int/resource/docs/2013/cop19/eng/10a01.pdf (accessed on 5 May 2015)

Dales JH (1968) Land, Water and Ownership. The Canadian Journal of Economics 1(4): 791-804

Dales JH (1975) Beyond the Marketplace. The Canadian Journal of Economics 8(4): 483-503

Dales JH (2002) Pollution, Property and Prices. Cheltenham: Edward Elgar

Darby M (2014) China and US Presidents to Attend Ban Ki-moon Climate Summit. Responding to Climate Change, 15 August. Available at: 
http://www.rtcc.org/2014/07/23/china-and-us-presidents-to-attend-ban-ki-moon-

climate-summit/ (accessed on 5 May 2015)

Davenport C (2014) Emissions From India Will Increase, Official Says. The New

York Times, 24 September. Available at:

http://www.nytimes.com/2014/09/25/world/asia/25climate.html? r $r=0$ (accessed on 5

May 2015)

Davey E (Secretary of State for Energy and Climate Change) (2014) UK Hails

Successful Start to Fifteen Months of Climate Diplomacy. DECC Press Release, 24

September. Available at: https://www.gov.uk/government/news/uk-hails-successful-

start-to-15-months-of-climate-diplomacy (accessed on 5 May 2015)

Energy Act 2013 c 32

Environment, Food and Rural Affairs Committee (2007) Draft Climate Change Bill:

Fifth Report. HC 534-I (2006-07).

European Commission (2010) International Climate Policy Post-Copenhagen: Acting

Now to Reinvigorate Global Action on Climate Change. COM(2010) 86 final (9

March 2010). Available at:

http://eurlex.europa.eu/LexUriServ/LexUriServ.do?uri=SEC:2010:0261:FIN:EN:PDF

(accessed on 13 September 2015)

European Commission (2015) The Paris Protocol: A Blueprint for Tackling Global

Climate Change Beyond 2020. COM(2015) 81 final/2 (4 March)

European Parliament and Council of the European Union (2009) On the Effort of

Member States to Reduce their Greenhouse Gas Emissions to Meet the Community’s

Greenhouse Gas Emission Reduction Commitments Up to 2020. Decision 
406/2009/EC (23 April 2009). Available at: http://eur-lex.europa.eu/legalcontent/EN/TXT/?uri=CELEX:32009D0406 (accessed on 5 May 2015) Global Carbon Project (2014) Global Carbon Budget 2014. Available at: http://www.globalcarbonproject.org/carbonbudget/index.htm (accessed on 5 May 2015)

Gosden E (2014) ‘Green Energy Targets Cannot Be Cut, Government Adviser Says’. Daily Telegraph, 11 December. Available at:

http://www.telegraph.co.uk/finance/newsbysector/energy/10509744/Green-energytargets-cannot-be-cut-government-adviser-says.html (accessed on 5 May 2015) Gupta J and Chaudhary J (2014) BASIC Group Refuses to Budge on Climate Change Stance. Chinadialogue, 8 August. Available at: https://www.chinadialogue.net/blog/7212-BASIC-group-refuses-to-budge-on-climatechange-stance/en (accessed on 5 May 2015) Harribin R (2014) Wavering on UK Climate Policy “Not Justified”. BBC News, 7 November. Available at: http://www.bbc.co.uk/news/science-environment-24834697 (accessed on 5 May 2015) Harvey F (2015) Current Carbon Pledges Won’t Stop Dangerous Global Warming, Says Lord Stern. The Guardian, 4 May. Available at:

http://www.theguardian.com/environment/2015/may/04/current-carbon-pledges-wontstop-dangerous-global-warming-says-lord-stern (accessed 5 May 2015)

HM Government (2012) Meeting the Carbon Budgets: 2012 Progress Report to Parliament. Available at: https://www.gov.uk/government/policies/reducing-the-uk-sgreenhouse-gas-emissions-by-80-by-2050/supporting-pages/carbon-budgets (accessed on 5 May 2015) 
Heyvaert V (2011) Governing Climate Change: Towards a New Paradigm for Risk Regulation. Modern Law Review 74(6): 817-44

Iharhara N (Japanese Minister of the Environment) Statement at COP19/CMP9.

Available at: http://unfccc.int/meetings/warsaw_nov_2013/statements/items/7878.php (accessed on 5 May 2015)

Intergovernmental Panel on Climate Change (2007) Climate Change 2007: Mitigation of Climate Change. Cambridge: Cambridge University Press

Majone G (1994) The Rise of the Regulatory State in Europe. West European Politics 17(3): 77-101

McGrath M (2013) Mood of “Realism” about Future Deal at Climate Talks. BBC

News, 11 November. Available at: http://www.bbc.co.uk/news/science-environment-

$\underline{24857163}$ (accessed on 5 May 2015)

Ministry of Foreign Affairs of Japan (2010) Japan’s Position Regarding the Kyoto

Protocol. December. Available at:

http://www.mofa.go.jp/policy/environment/warm/cop/kp_pos_1012.html (accessed on 13 September 2015)

Moran M (2003) The British Regulatory State. Oxford: Oxford University Press

Orwell G (2001/1946) Why I Write'. In: Orwell, G Complete Works, vol 18 (London: Secker and Warburg, pp.316-21

Osborne D (2014) Climate Change Summit: Brazil Refuses to Sign UN’s Pledge to Slow Deforestation. The Independent, 23 September. :

http://www.independent.co.uk/news/world/americas/climate-change-summit-brazilrefuses-to-sign-un-pledge-to-slow-deforestation-9751770.html (accessed on 13 April 2014) 
Paterson O (former Secretary of State for Environment, Food and Rural Affairs) (2014) Keeping the Lights On. 2014 Annual Global Warming Policy Foundation Lecture. Available at: http://www.thegwpf.com/owen-paterson-keeping-the-lights-on/ (accessed on 5 May 2015)

PBL Netherlands Environmental Assessment Agency (2014) Trends in Global $\mathrm{CO}_{2}$ Emissions: 2014 Report. Available at: http://edgar.jrc.ec.europa.eu/news_docs/jrc2014-trends-in-global-co2-emissions-2014-report-93171.pdf (accessed on 5 May 2015)

Press Trust of India (2014) Really Wanted Modi to Attend UN Climate Change Summit: Ban Ki-moon. The Indian Express, 17 September. Available at: http://indianexpress.com/article/india/india-others/really-wanted-modi-to-attend-unclimate-change-summit-ban-ki-moon/ (accessed on 5 May 2015) Prosser T (2005) The Regulatory Enterprise. Oxford: Oxford University Press Reklev S and Twidale S (2013) UN Talks Limp Towards Global 2015 Climate Deal. Reuters, 23 November. Available at: http://uk.reuters.com/article/2013/11/23/climate-

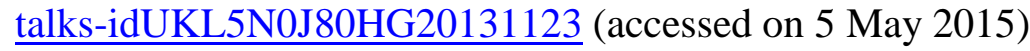
Ritter K (2013) Modest Deal Breaks Deadlock at UN Climate Talks. Associated Press, 23 November. Available at: http://news.yahoo.com/modest-deal-breaksdeadlock-un-climate-talks-183434640--finance.html (accessed on 5 May 2015) Rowling M (2014) UN Climate Envoy Says Summit Key to Reinvigorate Global Pact. Reuters, 11 September. Available at: http://www.reuters.com/article/2014/09/11/usfoundation-climatechange-robinson-idUSKBN0H60R820140911 (accessed 5 May 2015) 
Scislowska M and Ritter K (2013) Activists Walk Out of UN Climate Talks After

“Frustration” and “Disappointment”. Associated Press, 21 November. Available at: http://www.huffingtonpost.com/2013/11/21/un-climate-talks_n_4317094.html (accessed on 5 May 2015)

Stallworthy M (2009) Legislating Against Climate Change: A UK Perspective on a Sisyphean Challenge. Modern Law Review 72(3): 412-62

Stern N (2007) The Stern Review. Cambridge: Cambridge University Press Stern, N (2015) Why Are We Waiting? Cambridge MA: MIT Press

Su Wei (Director General, PRC Department of Climate Change) (2010) Letter to Mr Yvo de Boer, Executive Secretary, UN Climate Change Secretariat. 28 January. 2010. Available at:

http://unfccc.int/files/meetings/cop_15/copenhagen_accord/application/pdf/chinacpha ccord_app2.pdf (accessed on 5 May 2015)

Sunstein C (1990) After the Rights Revolution: Reconceiving the Regulatory State.

Cambridge, Mass: Harvard University Press

United Nations (1988) Protection of Global Climate for Present and Future

Generations of Mankind. 70th Plenary Meeting of the General Assembly, A/RES/43/53, 6 December. Available at:

http://www.un.org/en/ga/search/view_doc.asp?symbol=A/RES/43/53\&Lang=E\&Area =RESOLUTION (accessed on 30 September 2014)

United Nations (1992) Framework Convention on Climate Change. 1771 UNTS 107, opened for signature 9 May 1992, entered into force 21 March 1994 
United Nations (1997) Kyoto Protocol to the United Nations Framework Convention on Climate Change. 2302 UNTS 148, opened for signature 11 December 1997, entered into force 16 February 2005 United Nations Climate Change Secretariat (nd) Warsaw Outcomes. UNFCCC website. Available at: http://unfccc.int/2860.php (accessed on 5 May 2015) United Nations Environment Programme, The Emissions Gap Report 2014. Available at:

http://www.unep.org/publications/ebooks/emissionsgapreport2014/portals/50268/pdf/ EGR2014_LOWRES.pdf (accessed on 5 May 2015)

Webster B (2013) China Outstrips Europe in Greenhouse Gas Emissions. The Times, 19 November. Available at:

http://www.thetimes.co.uk/tto/news/world/article3925566.ece (accessed on 5 May 2015)

Westcott L (2014) UN’s Climate Change Push Gains DiCaprio but Loses India, China and Russia. Newsweek, 17 September. Available at: http://www.newsweek.com/banki-moon-climate-change-focus-general-assembly-270993 (accessed on 5 May 2015) Williams Jr EW and Coase RH (1964) Discussion. American Economic Review (Papers and Proceedings) 54(3): 192-97

World Bank (2010) World Development Report 2010: Development and Climate Change. Washington DC: World Bank. Available at:

http://siteresources.worldbank.org/INTWDR2010/Resources/5287678-

1226014527953/WDR10-Full-Text.pdf (accessed on 5 May 2015)

Zhang Gaoli (Special Envoy of President Xi Jingping and Vice Premier of the State Council of China) (2014) Address by His Excellency Zhang Gaoli to the UN Climate 
Summit. 23 September. Available at:

http://statements.unmeetings.org/media2/4628014/china_english.pdf (accessed on 5

May 2015)

\section{Acknowledgements}

Earlier versions of the original article were presented to the Cardiff Law School, Cardiff University, the Plymouth Law School, Plymouth University and the Lancashire Law School, University of Central Lancashire. I am grateful to the audiences at those presentations and to Bob Lee, Matthias Klaes, Chandran Kukuthas, Tom Poole, Tony Prosser and Peter Shears for their comments. I wish emphatically to stress that I alone am responsible for the contents of this article.

\section{Notes}

${ }^{1}$ The principal result of the Summit was a 'declaration' about deforestation which, not only was merely tangential to the point of the Summit, but was itself completely undermined as Brazil, itself a newly industrialising country which generally forms a negotiating bloc with China and India on emissions agreements, refused to be party to it (Osborne, 2014).

${ }^{2}$ Though international global warming policy discussions can be traced to the 70 s, for the purposes of evaluating its performance, the UN process is most usefully dated from the creation of the Intergovernmental Panel on Climate Change in 1988: (UN, 1988: para 5).

${ }^{3}$ On China’s Country Statement at the Summit see n 9 below. India does not appear to 
have made a Country Statement. The day after the Summit, the new Indian Minister for the Environment, Mr Prakash Javadekar, categorically stated that India will, not merely refuse to agree a global reductions obligation, but will very significantly increase its own emissions (Davenport, 2014).

${ }^{4}$ Though itself intensely disputed, not least by the CCC (2014c), the most accurate influential summary statement is Paterson (2014).

${ }^{5}$ Part 2 of the Review, not relevant to us here, was published on 11 December 2013. ${ }^{6}$ The principal sources of data subsequent to the papers of my colleagues and myself are: Global Carbon Project (2014), PBL Netherlands Environmental Assessment Agency 2014), United Nations Environment Programme (2014) and updatings by the World Bank of the information collected in World Bank (2010).

${ }^{7}$ The contrasting features of the Environment Agency itself are put in their regulatory context in Prosser (2005: ch 4).

${ }^{8}$ On this occasion, 'frustration', ‘disappointment' and ‘anger’ led to a mass walk-out by activists, including many of the most influential NGOs (Friends of the Earth, Greenpeace, Oxfam, etc) (Scislowska and Ritter, 2013).

${ }^{9}$ China’s Country Statement at the New York Summit essentially repeats this notification (Zhang Gaoli 2014).

${ }^{10}$ Japan's abandonment of the Kyoto process means that none of the five largest emitters, responsible for $60 \%$ of emissions, have any Kyoto commitments, a point which does not emerge from the Review.

${ }^{11}$ On the EU dimension see Heyvaert (2011).

${ }^{12}$ I must make it clear that Klaes is not responsible for this afterword; indeed he has 
advised against its publication in this form.

${ }^{13}$ Dales’ own views are much more sophisticated than they are presented in most environmental law scholarship: Dales (1975).

${ }^{14}$ One of the major difficulties of the EU System is, however, the undermining of 'supplementarity’ which follows from 'offsetting' claimed overseas reductions against EU emissions, and this is not in principle resolvable, save by abandoning offsetting, and with this the Clean Development Mechanism. The Commission's response to this difficulty has been to continue with offsetting, but to reduce the amount permitted. ${ }^{15}$ In the UN negotiating process the precise status to be given to what is agreed in Paris has so far been left open.

${ }^{16}$ After this Afterword was written, Lord Stern sought to prepare for the failure of the Paris Conference in statements to the media insisting that, even though no actual reductions agreement would be reached, progress would be made (Harvey, 2015). In the report that gave rise to these statements he and his colleagues now tell us that 'The ambitions and plans agreed at the Paris summit in December 2015 should be regarded as a critical initial step’ (Boyd, Stern and Ward, 2015: 12)! They were moved to talk in this simultaneously scarcely believable and entirely predictable way by examination of the intended 'nationally determined contributions' communicated to the Secretariat in advance of the Paris Conference). These were similar to notifications under the Copenhagen Accord and were similarly utterly unpromising, so unpromising, in fact, that even Lord Stern had to let some perception of reality affect his former enthusiasm for the Paris Conference, and to makes this relatively clear recantation, no doubt the first of many. But it should be noted that the process of Lord 
Stern's attempt to withdraw from expectation of the UN negotiating process yielding a binding emissions reduction agreement antedates The Carbon Budget Review (Stern, 2015: xviii). 